\title{
Faculty Format Preferences in the Performing Arts: A Multi-Institutional Study
}

\author{
Joe C. Clark, Jonathan Sauceda, and Sheridan Stormes
}

Resources for teaching in higher education have undergone a tremendous evolution during the past several decades. The Internet and commercial services, such as YouTube and Google, have revolutionized the manner by which students and faculty access information to both conduct research and meet course requirements. This mixed methods study implemented an online survey and interviews to determine how performing arts faculty at three institutions integrate library resources and services into their teaching. Conclusions indicate that, while personal collections and Internet resources provide a majority of teaching content, the academic library still offers important access to materials for instruction.

\section{Introduction}

Most performing and visual arts faculty use a wide variety of materials for student instruction, which include music scores and audiovisual resources, in addition to books and journals. Up until the last several decades, most faculty relied on print and physical media materials available from their personal collections and libraries. However, technological developments such as the CD-ROM, online library full-text databases, and e-books have changed the way they access information. The internet now offers free, freemium, and subscription products such as YouTube, Spotify, Pandora, IMSLP, and various open-access digitized scores collections. These resources provide faculty with vast options, many of which circumvent the library. Faculty members, like their students, appear to value convenience, usability, and ease of access.

Given this environment, librarians at three universities conducted an online faculty survey in the disciplines of music, theatre, dance, and arts administration to determine the library's role in performing arts instruction. To deepen their understanding of how faculty view the library and other resources, the authors also conducted individual follow-up interviews that allowed them to obtain more specific information on how faculty view pedagogical resources and what drives their choices.

The goal was to answer the following questions: 1) How do faculty use the library to support their teaching? 2) What materials and formats would faculty prefer the library purchase

\footnotetext{
* Joe C. Clark is Head, Performing Arts Library, and Associate Professor at Kent State University; email: jclark88@ kent.edu. Jonathan Sauceda is Music and Performing Arts Librarian in the New Brunswick Libraries at Rutgers University; email: jonathan.sauceda@rutgers.edu. Sheridan Stormes is Professor and Performing E Fine Arts Librarian at Butler University; email: sstormes@butler.edu. (C2019 Joe C. Clark, Jonathan Sauceda, and Sheridan Stormes, Attribution-NonCommercial (http://creativecommons.org/licenses/by-nc/4.0/) CC BY-NC.
} 
to support their teaching? 3) How satisfied are faculty with current library holdings? 4) What obstacles do faculty encounter in using library resources? and 5) What nonlibrary mediated resources are faculty using in instruction, and why?

\section{Background}

Performing arts faculty from Kent State University, Butler University, and Rutgers University participated in this study. These institutions offer similar programs yet have some variety in student population, geography, and means of support. The study was conducted by librarians who served as liaisons for music, theatre, and dance at their respective institutions.

Located in Northeast Ohio, Kent State University is the state's second largest public university with approximately 29,000 students. During this study, the School of Music had roughly 125 undergraduates and 65 graduate students in residence, while the School of Theatre and Dance had approximately 273 undergraduates and 16 graduate students. The faculty population was approximately 18 in theatre, 7 in dance, and 52 in music. The Performing Arts Library is in the Center for the Performing Arts, which hosts the university's music, theatre, and dance classes.

Rutgers-New Brunswick, the flagship campus of Rutgers, The State University of New Jersey, is a Carnegie-Classification Highest Research Activity institution. Its campus had approximately 42,000 students enrolled during the study, with nearly 800 in music, theater, and dance. ${ }^{1}$ The Mason Gross School of the Arts grants bachelor's and master's degrees in each of those programs as well as PhDs and DMAs in music. ${ }^{2}$ The School had 77 music faculty, 29 theatre faculty, and 27 dance faculty teaching at the time of the study; these included full-time and adjunct positions. The collections for theatre, dance, and music are held in the Blanche and Irving Laurie Performing Arts Library, which is a standalone library near the performing arts buildings. Rutgers University has many more graduate students in the performing arts than either Kent State or Butler.

Butler University is a liberal arts-based, private not-for-profit university situated just a few miles north of downtown Indianapolis, Indiana. In recent years, Butler has become primarily a residential campus. It had a total F.T.E. of 4,945 during the study; those totals included Jordan College of the Arts' F.T.E. undergraduate enrollment of 366 (22 art+design, 91 arts administration, 76 dance, 147 music, and 30 theatre). Graduate music enrollment was 40 . The full-time faculty was composed of 26 in music, nine in dance, six in theatre, and five in either arts administration or art and design; these numbers exclude the 43 adjuncts who served the School. The library collections supporting these programs are housed in the campus's main (that is, Irwin) library and are managed by the Performing \& Fine Arts Librarian.

All three libraries in this study offered similar holdings, which included a strong print score collection, streaming and physical media collections, print and electronic reference titles, and print and electronic books. At present, Butler and Rutgers subscribe to a score database (A-R Editions' Online Music Score Anthology and Alexander Street's Classical Scores Library respectively). Kent State University Libraries' have a strong Patron-Driven Acquisition program for e-books, and Butler began a similar program in 2016.

\section{Literature Review}

This study explores a number of distinct but related issues: preferences for electronic versus physical media, the needs of faculty members in their role as teachers, and special requirements 
of performing arts disciplines. The literature has previously dealt with each of these questions, but not in the same study. In terms of the move to digital formats, journal subscriptions have displaced print entirely for many users. ${ }^{3}$ Electronic books have fared less successfully in libraries; many patrons continue to assert preference for physical media (although reference works appear to be an exception). ${ }^{4}$ Researchers at the University of Toronto found that, for Library of Congress M classification materials (which include printed music and books about music), 1.36 print books were used for every e-book. ${ }^{5}$

Becker posited that a shift favoring e-books began around 2010 when the iPad premiered. ${ }^{6}$ Preferences for print often have involved discontent with the interface and other limitations of e-books. However, these concerns have abated over time as users have become more accustomed to using digital media. The authors of "Electronic versus Traditional Print Textbooks" found that, not only has electronic textbook use been increasing, but there has not been a measureable difference in student comprehension of e-text compared to that of print. ${ }^{7}$

Still, studies show that preferences can vary widely by field; therefore, discipline-specific investigations may offer a better view of the desires of particular information communities. Levine-Clark found that humanities scholars at the University of Denver favored print books. ${ }^{8}$ Elsewhere, humanities and fine arts affiliates had the highest levels of "book lover" identity compared with those in other disciplines-meaning they primarily valued the physical form of the book and disdained long-form reading on digital devices. In interviews conducted with dance faculty at three institutions, Robinson found that 100 percent $(n=12)$ preferred print books to electronic. ${ }^{9}$ A study of humanities faculty members at Florida State University challenged these results, however. It found that emotional attachment to print was less influential than had been believed, and that users more highly valued the accessibility and interactivity that e-books afford..$^{10}$ This seems to confirm Becker's proposed preference shift toward e-books.

Music scores, heavily used in many performing arts disciplines, are now widely available online. IMSLP/Petrucci Music Library has offered digital scores in the public domain since 1998, and vendors like Alexander Street Press make printed music available through their Classical Scores database. ${ }^{11}$ The complete works of composers such as Carl Philipp Emanuel Bach (1714-1788) and Wolfgang Mozart (1756-1791) are freely available online. ${ }^{12}$ The Society for Seventeenth-Century Music publishes peer-reviewed musical editions on the Web Library of Seventeenth-Century Music, which is openly accessible. ${ }^{13}$ Still, studies from 2010 onward indicate a decided preference for print scores. ${ }^{14}$

Regarding audio and video access preferences, Procell's ten-year study at the University of Louisville noted an increase in patron use of subscription streaming media databases as well as a corresponding decline in circulation of physical items. ${ }^{15}$ While library-paid services seem to remain heavily used, free and freemium sites have become an important part of the information landscape. Dougan found that a majority of faculty respondents used YouTube to supply at least some listening examples for their classes. ${ }^{16}$ The vast majority $(83 \%)$ of the dance faculty Robinson interviewed identified YouTube as their primary video source. Forty-two percent also used DVDs, while only 25 percent used Alexander Street's Dance in Video. ${ }^{17}$ In terms of audio preference for dance faculty, iTunes $(n=7)$ was the most popular, followed by CDs $(n=5)$, live music $(n=5)$, Spotify $(n=3)$, and Naxos $(n=1)$. YouTube was not mentioned at all. ${ }^{18}$ Clark and Evans' 2014 study found that music majors were more likely to use library CDs than nonmajors. They also found that YouTube and free music streaming services were chosen more frequently than streaming library audio databases and reserves for coursework. ${ }^{19}$ 
Based on Clark's 2013 examination of performing arts students' format preferences, Huddlestun's research explored what format and material types music faculty at Kennesaw State University wanted more of, what they used, and their material format preferences. ${ }^{20} \mathrm{He}$ found that, in addition to a preference for print books and scores, there was a strong desire for electronic access to video, journals, reference materials, and audio. ${ }^{21}$

Dougan noted that it is not clear whether faculty still expect the library to be students' primary audio source. She also identified a dichotomy between using YouTube for instructional purposes and preferences for their own scholarly work. ${ }^{22}$ Dougan questioned why faculty did not require that students use library-provided streaming resources. She offered inconvenience, lack of content, or ignorance as possible reasons, and recommended a follow-up study. ${ }^{23}$

Among the themes that emerge in our literature review is a trend toward more acceptance of, and preference for, electronic formats, especially regarding reference, journal, audio, and video content. Regarding audio and video content, users seemed more concerned that the material is easily and immediately accessible than with its legality, future availability, or quality. Variance among academic fields, however, necessitates discipline-specific study. The following qualitative and quantitative results from three unique universities provide additional information on these and other themes that are specific to faculty and performing arts instruction.

\section{Methodology}

This mixed-methods study, which consisted of an online survey and faculty interviews, was approved by the Institutional Review Boards at all three participating universities. The authors developed the survey and interview questions together. They conducted interviews during the survey window. Participation for both was open to all performing arts faculty members. The survey (see appendix A) was administered in Qualtrics through the account at Kent State University, and the primary investigator distributed unique survey links with embedded university data to distinguish affiliation. Each author recruited their respective faculty for survey participation via email invitations using departmental listservs.

The investigators downloaded survey data into SPSS 23 for analysis, then exported some results into Microsoft Excel for its chart and table abilities. Most survey items were multiple choice or multiple selection; the primary investigator summarized these using counts and proportions. Faculty were asked to rank what they wanted the library to prioritize for purchase, with 1 representing the highest priority; these are reported using means and standard deviations. The survey also asked participants to describe what proportion of their course materials came from various sources; these are also reported using means and standard deviations.

When selecting faculty for interviews, all three authors attempted to include representative users from the various arts disciplines (ethnomusicology, music technology, music education, dance history, dance education, costume design, playwriting, and others). At Kent State University, the survey invitations sent via the listserv provided interview information, and several faculty volunteered. Not all were selected for an interview, as the goal was to obtain a representative sampling. Each author interviewed 10 to 15 faculty members.

The interviews consisted of seven major questions (see appendix B). The intention was to uncover reasons for faculty behavior as well as underlying opinions about the library and its role. Because subjects for both the survey and interviews were teaching faculty in the 
performing arts, completion of the online survey was not a prerequisite for interviews. The authors believe that most, if not all, of the interviewees completed the anonymous survey.

The investigators recorded the interview sessions with music, theatre, and dance faculty at their respective universities and later transcribed them. They compiled the transcriptions in Microsoft Word. The primary investigator used open coding, with data iteratively reviewed and developed for codes. ${ }^{24}$ We coded segments of data relevant to our research questions and interspersed interview results with the survey results in this paper to provide rationale and examples of faculty behavior and preferences.

\section{Results and Discussion Demographics}

Of the 65 faculty members who completed surveys, 26 were at Kent State University, 25 at Butler University, and 14 at Rutgers University. The response rate was highest at Butler, where 54 percent of full-time performing arts faculty participated. Thirty-two percent of faculty at Kent State completed the survey, while the Rutgers rate was 11 percent. The completion rate among the three disciplines was 24 percent for music, 31 percent for dance, and 17 percent for theatre faculty.

A majority were full-time tenure-track or tenured faculty $(60 \%, n=39)$, and 26 percent ( $\mathrm{n}$ $=17$ ) were full-time nontenure track. Adjunct faculty, who can comprise a higher percentage in music schools due to the need for considerable instrumental expertise, were 12 percent of those surveyed. One graduate assistant who taught a class and had received the invitation via the departmental listserv also completed the survey.

Participants exhibited a wide range of ages and years of teaching experience in higher education. Slightly more than one quarter were 40 years old or younger, and just less than 20 percent were 61 or older. Years teaching were fairly evenly distributed, with about one-third having 10 years or fewer, one-third with between 11 and 20 years, and just over a third with 21 years or more teaching in higher education.

Sixty-three of the 65 participants identified a discipline. A majority $(60 \%)$ were in music. Almost half (45\%) of those were involved in performance/conducting. Music education, music history/musicology, ethnomusicology, and theory/composition each comprised about 14 percent of the music faculty respondents. Thirteen dance faculty accounted for 21 percent of the participants, while 14 percent $(n=9)$ were in theatre. Unfortunately, the pool did not provide an adequate number to make statistically valid comparisons between the disciplines at each university.

\section{Materials Used in Instruction}

Faculty required their students to use a variety of material types. In answer to the question, "When teaching courses, what materials do you typically require students to use?" "textbooks" was the most common response, used by almost two-thirds of faculty. Audio and video were also near the top of the results, with 60 percent and 57 percent requiring said content respectively. Journal articles, scores, and books/book chapters were required by roughly half of the faculty, and reference materials by about one-third.

Do faculty expect students to use library resources to secure these materials? It was apparent that some formats were more likely to be required from the library than others. Faculty were less likely to assign library resources for content that was freely accessible online, such 
as audio and video (see table 1). Only 21 percent of those who made listening assignments required library CDs, and 26 percent directed students to the library's streaming audio databases. Similarly, relatively few faculty required video through library resources: 24 percent used library DVDs, and 22 percent used the library's streaming video databases. This is in spite of the fact that video and audio are among the most required types of content for students in the performing arts.

Some library resources were required at a much higher rate. Sixty-eight percent of faculty who required book content mandated library books (print or electronic). Similarly, 56 percent of those who assigned coursework involving

\begin{tabular}{|l|c|}
\hline \multicolumn{2}{|c|}{ TABLE 1 } \\
\hline Format & $\begin{array}{c}\text { Percentage Requiring } \\
\text { Said Content That Use } \\
\text { Library Resources/ } \\
\text { Formats }\end{array}$ \\
\hline Books/book chapters & $68 \%$ \\
\hline E-reference & $61 \%$ \\
\hline Journal articles & $56 \%$ \\
\hline Print reference & $39 \%$ \\
\hline Scores & $36 \%$ \\
\hline Streaming audio DBs & $26 \%$ \\
\hline DVDs & $24 \%$ \\
\hline Streaming video DBs & $22 \%$ \\
\hline CDs & $21 \%$ \\
\hline
\end{tabular}
journal content referred students to the library.

Required use of library reference materials skewed toward the library's electronic access over print at a ratio of 61 percent to 39 percent.

Faculty interviews explained the prevalence of nonlibrary audio and video resources. One brass professor stated that his go-to audio source during lessons was YouTube

... for the convenience of being right in my studio, to be able to pull it up at my fingertips, and have a student listen to a piece that we are considering working on, or a style that we are working towards, rather than take the time to go somewhere else to find a recording.

He then would forward the selected video's link to the student for further study. Ease of access and familiarity appear to contribute heavily to this behavior. One dance faculty member said that the internet "is at my fingertips, and I know that you are right in the building, but this is at my fingertips, and I am looking up Anything Goes ... and there she is." An ethnomusicologist said that "I always go with YouTube, because there are just so many resources, and it is easy, and I can always find what I need, and it is quick..." Another ethnomusicologist reaffirmed the notion of YouTube's variety and breadth, remarking that "it is abundant compared to anything we [the library] could offer" and allows him to find content the library simply doesn't possess.

Retrieval of physical media is an extra, unwanted step: one music instructor confessed that "these days if I need an extra piece I don't have, I'm not familiar with, I want to play it, I tend to go to YouTube first just because it spares the trouble of having to come in to check out a CD."

In addition to familiarity with and ease of access to online resources, convenience was a major reason faculty chose virtual items over physical media. One music faculty member recalled a time when she brought many items into class to play, but now "it is just all in one place [online], I don't have to bring in physical things, I just bring my computer in and boom." A theatre faculty member stated that "often I will look for YouTube videos or things like that because usually I 
haven't planned ahead far enough to go [use] the library." A theatre history professor declared that he was "used to Googling," and went on to state that "the reason that I think I use that [the internet] is they [videos] are convenient and easy to find - I can sit there at 2 in the morning and look up something, not that they are the best, but they are the easiest to come by."

Responses to the survey question, "Do you require students to use library resources, or are they free to acquire the information however they can?" resulted in a tie, with 32 responses for each. It was clear through the faculty interviews that they expected students to purchase some materials as professionals in training, while library resources served as supplements. One music professor giving many private instrumental lessons remarked that:

there are etudes that I use every semester for the duration [of a student's program], books that we constantly refer to, and then as I want them to branch out into other styles, we may do three or four weeks of etudes out of one book that we use from the library and then another book - that is when I use more library materials.

To help establish what nonlibrary materials faculty used in instruction, the authors posed the survey question, "What types of formats do you use in your teaching/instruction that are NOT from the library (list all that apply)?" The question offered a list of prepopulated responses and the ability to check "other" and list in a text box. The results were as follows:

- Freely available media from the internet (such as YouTube or Spotify): $83 \%$

- Personal media (CDs, DVDs): $63 \%$

- PDF/text files loaded into course management system (such as Blackboard, Moodle, eCollege, or Canvas): $55 \%$

- Media files loaded into course management system (such as Blackboard, Moodle, eCollege, or Canvas): $45 \%$

- Other: $12 \%$

Most faculty used the internet in their instruction. As noted previously, convenience, ease of access, and familiarity with internet resources were the primary reasons why faculty accessed these resources. Of the eight replies for "other," five included personal materials (scores, books, electronic files, and the like), two listed internet content (including imslp.org and blog posts), and one cited e-reserves through the library.

Both interviews and survey data revealed that faculty made available many of their readings, which may have originated in the library, via course management software. The primary reason for doing this was to guarantee student access. One faculty member stated that it ensures that "there is no excuse for them going to read a specific article, because if I say go to JSTOR, then I get that 'I don't know how to do it' or 'I couldn't find the VPN or whatever'; if I put it in Blackboard ... there are no excuses." A faculty member in music technology noted, "The problem is that any barrier to access beyond putting a link means that a significant portion of students just won't do that work." In other words, once students have completed a course, they will have had little experience in finding materials in that subject independently, which makes future research more difficult.

To further gauge the sources of teaching materials, the authors had survey participants complete a percentage table totaling 100 percent to indicate which types of resources they used and to what degree. It was clear that most drew from a variety of sources: 97 percent depend on personal materials, 94 percent use content from the internet, and 87 percent use 
library resources. "Other," which 17 percent of faculty used in teaching, were either purchased by students (textbooks or other resources) or borrowed from colleagues or other institutions.

Based on the percentages, materials from one's personal collection were most common, averaging 44 percent. Internet and library content garnered almost the same percentage, with 26 percent and 25 percent respectively. These three aforementioned sources accounted for most of the teaching materials, as "other" was selected by only 17 percent of faculty and averaged 30 percent for those who used other sources (and averaged 5 percent overall).

\section{Library Resources}

The authors explored faculty sentiments about library resources and services through five inquiries: 1) satisfaction with the existing library collection; 2) ideas on what the library could purchase more of; 3) use of existing collections and services; 4) obstacles to using library resources and services; and 5) an open-ended question about things the library could do to support instruction.

Survey questions regarding satisfaction with the existing library collections also revealed what faculty do not use (see table 2). Some formats were more popular with some disciplines; for example, two-thirds of theatre and dance faculty did not use music scores or CDs and used library streaming audio databases only minimally. Most library resources were not used by approximately one-third of faculty, but some received more use than others. Only 9 percent of respondents reported not using library books at all. Electronic journal databases and electronic reference materials were close behind with 19 percent and 21 percent of nonuse respectively. It is worth noting that faculty were generally most satisfied with materials often associated with humanities disciplines, namely print books, as well as those generally used by all fields-electronic reference materials and electronic journal databases.

Streaming video stood out as the most underutilized; 45 percent of respondents claimed they do not use their streaming library video databases. Satisfaction (a combination of very satisfied and satisfied) was also low for e-books (32\%), DVDs (25\%), print journals (34\%), and print reference materials (35\%). Levels of dissatisfaction were less than 9 percent for all items.

\section{TABLE 2}

Faculty Satisfaction with Existing Library Collection, Presented by Content Type

\begin{tabular}{|l|c|c|c|c|c|c|}
\hline \multicolumn{1}{|c|}{ Format } & $\begin{array}{c}\text { Very } \\
\text { Satisfied }\end{array}$ & Satisfied & Neutral & Dissatisfied & $\begin{array}{c}\text { Use but Don't } \\
\text { Know }\end{array}$ & Do Not Use \\
\hline Print books & $17 \%$ & $52 \%$ & $13 \%$ & $8 \%$ & $2 \%$ & $9 \%$ \\
\hline E-books & $8 \%$ & $24 \%$ & $23 \%$ & $2 \%$ & $7 \%$ & $37 \%$ \\
\hline CDs & $15 \%$ & $34 \%$ & $7 \%$ & $7 \%$ & $5 \%$ & $34 \%$ \\
\hline Streaming audio & $26 \%$ & $26 \%$ & $13 \%$ & 0 & $2 \%$ & $34 \%$ \\
\hline DVDs & $9 \%$ & $16 \%$ & $27 \%$ & $8 \%$ & $9 \%$ & $31 \%$ \\
\hline Streaming video & $10 \%$ & $16 \%$ & $21 \%$ & $3 \%$ & $5 \%$ & $45 \%$ \\
\hline Print journals & $10 \%$ & $24 \%$ & $32 \%$ & $3 \%$ & $3 \%$ & $29 \%$ \\
\hline E-journal DBs & $36 \%$ & $19 \%$ & $21 \%$ & $2 \%$ & $2 \%$ & $19 \%$ \\
\hline Print reference & $10 \%$ & $25 \%$ & $19 \%$ & $6 \%$ & $6 \%$ & $33 \%$ \\
\hline E-reference & $23 \%$ & $36 \%$ & $11 \%$ & $2 \%$ & $8 \%$ & $21 \%$ \\
\hline Print scores & $11 \%$ & $32 \%$ & $13 \%$ & $6 \%$ & $8 \%$ & $30 \%$ \\
\hline
\end{tabular}


With one exception (print books), satisfaction with "electronic" formats of content was higher than for their physical counterparts. Faculty preferred the electronic journal and reference content over print and indicated slightly higher satisfaction with streaming audio and video over physical formats. They were more content with print books than with e-books, with 69 percent satisfied or very satisfied with print versus 32 percent satisfaction for e-books. Since only two of the three participating institutions had access to commercial score databases, this resource type was excluded from the survey question.

Regarding what materials the library should purchase more of, the authors asked: "What materials should the library prioritize for future purchase to support your instruction?" and a second question with carryover logic that asked respondents to rank-order their selected priorities. The results, shown in table 3, show strong support for additional print books, more so than for any other material type. Print books were the only material type that more than half of the faculty wanted more of $(60 \% ; n=39)$. This compares to 31 percent who wanted more e-books. The mean for ranking materials was lower for print books $(\mathrm{M}=2.86)$ than for e-books $(\mathrm{M}=3.50)$, indicating that print books were ranked as a higher priority.

- Some library content was obviously preferable in electronic format. The four most popular formats besides print books were electronic: journals, streaming video databases, reference databases, and streaming audio databases. On one hand, electronic journals ranked second with a mean of 2.57, second only to print scores. Print journals, on the other hand, were selected by less than one quarter of faculty, with a mean of 3.92. DVDs ranked even lower in percentage and mean, as did the print version of reference materials, which had the lowest percentage and the highest mean. Considering that 45 percent of survey participants reported not using the library's streaming video databases, it was interesting to see that 48 percent apparently wanted more of those databases. Although only 40 percent desired additional music scores, its mean was the lowest $(M=2.46)$. This suggests that the format was very important for those who did wish for more.

\begin{tabular}{|l|c|c|}
\hline \multicolumn{3}{|c|}{ MABLE 3 } \\
\hline Format & $\begin{array}{c}\text { Percentage of Faculty Who } \\
\text { Wanted More of Said Format }\end{array}$ & $\begin{array}{c}\text { Average Priority for Purchase } \\
\text { (1 is better) }\end{array}$ \\
\hline Print books & $60 \%$ & $M=2.86, n=37, s d=2.00$ \\
\hline Electronic journals & $51 \%$ & $M=2.57, n=30, s d=1.50$ \\
\hline Streaming video databases & $48 \%$ & $M=3.14, n=29, s d=1.51$ \\
\hline Electronic reference databases & $48 \%$ & $M=3.93, n=29, s d=2.39$ \\
\hline Streaming audio databases & $42 \%$ & $M=3.22, n=27, s d=1.58$ \\
\hline Print scores & $40 \%$ & $M=2.46, n=26, s d=1.96$ \\
\hline DVDs & $34 \%$ & $M=3.65, n=20, s d=1.98$ \\
\hline Score databases & $32 \%$ & $M=3.81, n=21, s d=2.50$ \\
\hline E-books & $31 \%$ & $M=3.50, n=20, s d=1.73$ \\
\hline Print journals & $23 \%$ & $M=3.92, n=13, s d=1.61$ \\
\hline CDs & $23 \%$ & $M=4.25, n=12, s d=2.01$ \\
\hline Print reference materials & $14 \%$ & $M=4.50, n=8, s d=2.33$ \\
\hline
\end{tabular}


Faculty did not indicate a strong desire to add print reference resources, CDs, print journals, e-books, score databases, or DVDs. In addition to garnering a low percentage (all were $<35 \%$ ), each of these formats had a high mean. Perhaps the instructors who wanted more of those materials actually ranked them as less important than other formats.

- Priorities emerged when the authors examined faculty responses to this item by their respective disciplines. The most favored item for dance faculty, by far, was streaming video databases $(69 \%, n=9)$; this was ranked second by the theatre faculty $(56 \%, n=5)$ and sixth for music faculty $(42 \%, \mathrm{n}=16)$. The top-ranked item for both music and theatre faculty was print books (68\% and 78\% respectively). Music faculty's second and third most commonly desired resources were electronic reference materials $(66 \%, n=25)$ and streaming audio databases $(61 \%, \mathrm{n}=23)$.

The authors also asked survey participants what library services they used. In general, music faculty made more use of library services than did faculty in dance and theatre (see table 4). Reserves were the most commonly used library service, as 63 percent used physical library reserves and 40 percent reported using electronic reserve services. ${ }^{25}$ Music faculty frequently used audio playlists and direct audio links provided by the library, while theatre and dance instructors were more likely to use direct video links from library databases. Responses provided in the "other" services category included consortial borrowing, Interlibrary Loan, and conversion of video files. Fifty-one percent claimed to have suggested specific titles for library purchase in support of class curriculum, and more than half of theatre and music instructors submitted titles for purchase.

Survey responses and interviews suggested that some students and faculty lacked information about library services and collections. Use of library instruction and orientation was low in music, theatre, and dance. One faculty member remarked that he had not taken advantage of as many library resources as expected "simply because the conversations that I have had with my students is that there seems to be a lack of awareness of those kind [li-

\begin{tabular}{|c|c|c|c|c|}
\hline \multicolumn{5}{|c|}{$\begin{array}{c}\text { TABLE } 4 \\
\text { Use of Library Services } \\
28\end{array}$} \\
\hline & $\begin{array}{c}\text { All } \\
\text { Disciplines }\end{array}$ & $\begin{array}{l}\text { Music } \\
(n=38)\end{array}$ & $\begin{array}{l}\text { Dance } \\
(n=13)\end{array}$ & $\begin{array}{c}\text { Theatre } \\
(\mathbf{n}=9)\end{array}$ \\
\hline Physical library reserves & $\begin{array}{c}63 \% \\
(n=41)\end{array}$ & $\begin{array}{c}76 \% \\
(n=29)\end{array}$ & $\begin{array}{c}54 \% \\
(n=7)\end{array}$ & $\begin{array}{c}44 \% \\
(n=4)\end{array}$ \\
\hline $\begin{array}{l}\text { I recommend specific titles for the library to purchase to } \\
\text { support my class curriculum }\end{array}$ & $\begin{array}{c}51 \% \\
(n=33)\end{array}$ & $\begin{array}{c}61 \% \\
(n=23)\end{array}$ & $\begin{array}{c}31 \% \\
(n=4)\end{array}$ & $\begin{array}{c}56 \% \\
(n=5)\end{array}$ \\
\hline Electronic library reserves & $\begin{array}{c}40 \% \\
(n=26)\end{array}$ & $\begin{array}{c}50 \% \\
(n=19)\end{array}$ & $\begin{array}{c}31 \% \\
(n=4)\end{array}$ & $\begin{array}{c}33 \% \\
(n=3)\end{array}$ \\
\hline $\begin{array}{l}\text { Playlists and direct link access to audio recordings } \\
\text { through the library }\end{array}$ & $\begin{array}{c}22 \% \\
(n=14)\end{array}$ & $\begin{array}{c}29 \% \\
(n=11)\end{array}$ & $\begin{array}{c}8 \% \\
(n=1)\end{array}$ & $\begin{array}{c}11 \% \\
(n=1) \\
\end{array}$ \\
\hline $\begin{array}{l}\text { Direct link access to video recordings through the } \\
\text { library }\end{array}$ & $\begin{array}{c}22 \% \\
(n=14)\end{array}$ & $\begin{array}{c}13 \% \\
(n=5)\end{array}$ & $\begin{array}{c}46 \% \\
(n=6)\end{array}$ & $\begin{array}{c}33 \% \\
(n=3)\end{array}$ \\
\hline Class instruction by a librarian ( 1 class or more) & $\begin{array}{c}22 \% \\
(n=14)\end{array}$ & $\begin{array}{c}24 \% \\
(n=9)\end{array}$ & $\begin{array}{c}31 \% \\
(n=4)\end{array}$ & $\begin{array}{c}11 \% \\
(n=1)\end{array}$ \\
\hline $\begin{array}{l}\text { Short library instruction by library personnel (15 } \\
\text { minutes or less) }\end{array}$ & $\begin{array}{l}14 \% \\
(n=9)\end{array}$ & $\begin{array}{l}21 \% \\
(n=8)\end{array}$ & $0 \%$ & $\begin{array}{l}11 \% \\
(n=1)\end{array}$ \\
\hline
\end{tabular}


brary] of resources." This statement, coupled with relatively low rates of library instruction, is troubling, as, without clear direction from faculty or librarians, it is unclear where students' awareness of and motivation to use library resources will come from.

In an effort to determine why faculty did not use the library more frequently, the authors asked survey participants, "What factors keep you from using (more) library resources in your classroom teaching/instruction (check all that apply)?" Only one reply garnered more than 18 percent: "The library does not have the materials that I need" (see table 5). This response was highest among music faculty (45\%), followed closely by those in dance (38\%). Twenty-six percent of music faculty cited inconvenience as a factor, while one (8\%) dance instructor and no theatre faculty selected this response.

\begin{tabular}{|l|c|c|c|c|}
\hline \multicolumn{7}{|c|}{ TABLE 5 } \\
Factors That Keep Faculty from Using Library Resources in Teaching \\
\hline Library does not have the materials that I need & $\begin{array}{c}\text { All } \\
\text { Disciplines }\end{array}$ & $\begin{array}{c}\text { Music } \\
(\mathbf{n = 3 8})\end{array}$ & $\begin{array}{c}\text { Dance } \\
(\mathbf{n}=\mathbf{3})\end{array}$ & $\begin{array}{c}\text { Theatre } \\
(\mathbf{n}=\mathbf{9})\end{array}$ \\
\hline Inconvenience & $\begin{array}{c}38 \% \\
(\mathrm{n}=25)\end{array}$ & $\begin{array}{c}45 \% \\
(\mathrm{n}=17)\end{array}$ & $\begin{array}{c}38 \% \\
(\mathrm{n}=5)\end{array}$ & $\begin{array}{c}22 \% \\
(\mathrm{n}=2)\end{array}$ \\
\hline Other & $\begin{array}{c}18 \% \\
(\mathrm{n}=12)\end{array}$ & $\begin{array}{c}26 \% \\
(\mathrm{n}=10)\end{array}$ & $\begin{array}{c}8 \% \\
(\mathrm{n}=1)\end{array}$ & 0 \\
\hline I don't know what the library offers or has available & $\begin{array}{c}18 \% \\
(\mathrm{n}=12)\end{array}$ & $\begin{array}{c}18 \% \\
(\mathrm{n}=7)\end{array}$ & $\begin{array}{c}15 \% \\
(\mathrm{n}=2)\end{array}$ & $\begin{array}{c}11 \% \\
(\mathrm{n}=1)\end{array}$ \\
\hline $\begin{array}{l}\text { Students have too much trouble using the library } \\
\text { website }\end{array}$ & $\begin{array}{c}8 \% \\
(\mathrm{n}=11)\end{array}$ & $\begin{array}{c}16 \% \\
(\mathrm{n}=6)\end{array}$ & $\begin{array}{c}23 \% \\
(\mathrm{n}=3)\end{array}$ & $\begin{array}{c}22 \% \\
(\mathrm{n}=2)\end{array}$ \\
\hline $\begin{array}{l}\text { Students have too much trouble locating and using } \\
\text { physical resources in the library }\end{array}$ & $\begin{array}{c}6 \% \\
(\mathrm{n}=5)\end{array}$ & $\begin{array}{c}11 \% \\
(\mathrm{n}=4)\end{array}$ & 0 & 0 \\
\hline
\end{tabular}

Twelve faculty listed other factors that kept them from using more library resources. Many of these dealt with access, convenience, and student expectations/desires. Library access comments included a suggestion for a book drop to facilitate return of physical materials and a complaint about the wait time for items for a regional campus faculty member with limited physical library resources at her/his location. Finding the time to go to the library was also mentioned in a few comments; one stated that "my teaching is nonstop, and I don't always have time to go to the library." Several comments brought up the ease of finding content: "I'm so overworked that I generally go for maximum ease in finding materials" and "If I can pull up a reference recording on YouTube in my computer, it's so much faster to find and to implement."

Fewer than 9 percent of faculty reported student problems as a factor in using library resources (see table 5); however, several comments indicated that student behavior and/or expectations impact library use. One remarked, "Students seem to find physical library reserves to be a pain ... I've had so much trouble convincing students to go get materials on physical reserve that I've been avoiding it." Another survey comment reflected student expectations: "Students seem to prefer/expect that materials be provided to them via our course management system, rather than having to go to the library themselves to use a physical reserve." 
Finally, one faculty member noted that "often students find the material from the internet" as a reason for not using library resources.

A final theme emerged in two comments concerning library processes and policy. One respondent stated: "While the services exist, they typically require significant lead time, and for the example of streaming audio, there are issues reusing materials from semester to semester." Another noted: "Materials borrowed through the consortia cannot be placed on reserve, and most library-owned things are in [their] personal collection or available as e-material."

The survey concluded by asking faculty to "please include any additional thoughts on how the library can support your classroom teaching/instruction." Replies touched on a number of topics. Several faculty members noted that they had not explored library holdings and services due to time constraints, while another perceived a lack of communication between the library and teaching faculty.

Several comments addressed print books and downloads. A faculty member wrote that "multiple copies of scripts would be really helpful." Another began their remarks with "more print books," but then wanted "a different format for our e-books. We need to be able to have e-books available to be downloaded/uploaded onto reading tablets such as Kindle or Nook [devices]." One comment praised the library's consortial services, then added that "the immediacy of today's education data access challenges the system. More downloads are needed, especially in scores." Finally, one suggested this:

It would be helpful if the library could have at least one, or even two, copies of major textbooks in their most recent editions... I envision running courses where reading assignments from textbooks will be optional, but helpful (e.g. for students who need to review material they find difficult). I don't think students should be required to buy a textbook in this case, so to be able to access a library copy would be really important. In addition, I think that the library should maintain up-to-date copies even of textbooks in music history and music theory that are not currently utilized for specific courses. These texts are often quite useful for graduate students as reference texts.

One particular comment summarized much of the survey data: "The library is indispensable for acquiring subscriptions (journals) and expensive items (like scores and hard-back books). Other things I can usually handle with personal copies or freely available material."

\section{Conclusions and Further Study}

Performing arts faculty required their students to use a number of formats in their coursework, not all of which were necessarily from the library. Journal articles, electronic reference materials, and books/book chapters were typically accessed through the library, while other content, such as audio and video, was more likely to be acquired from nonlibrary sources. The internet and its streaming services are the primary cause. Although faculty expressed a preference for library resources due to quality and reliability, the ease of access, vastness, and comfort level with internet resources made them difficult to resist. Eighty-three percent of faculty reported using freely available media from the internet, and 94 percent used internet content in their instruction. On average, instructors reported that about the same amount of materials came from the library (25\%) as from the internet (26\%). Personal collections supplied the highest amount (44\%). 
Faculty were generally content with the library collections. The highest level of satisfaction was for print books, electronic reference materials, and electronic journal databases. These formats, along with streaming video and audio databases, were the ones that faculty ranked highest for additional library purchases.

The study's data reaffirm all three institutions' current acquisition models, though it suggests some possible modifications toward more electronic resources. Kent State and Rutgers continue to purchase print books, while Butler orders books in electronic format unless otherwise specified by faculty. All libraries acquire print scores. Butler and Rutgers offer an online score database as well. All three libraries provide access to various streaming audio and video through Alexander Street Press (ASP)'s Music Online and Naxos Music Online and video databases such as ASP's Dance in Video and Kanopy. Butler purchases CDs and videos sparingly and plans to redirect more audiovisual funds to additional streaming resources. Kent State and Rutgers order physical media only when requested. All three libraries have canceled most print journal titles in favor of electronic access.

The participating librarians found this study's interviews very useful for exchanging information with faculty relating to pedagogy and library collections and services. These encounters furthered dialogue between both groups and have led to increased collaborations and awareness between them. The authors plan on continued, periodic meetings with individual faculty and groups of instructors. They also plan to improve awareness of library resources and information literacy skills of students and faculty through various means, including workshops and classroom sessions.

Although findings were fairly uniform across institutions, the authors encourage other librarians to conduct further investigations of faculty preferences to determine how best to meet local instructional needs. An important future topic is copyright and intellectual property. It was noteworthy that, when discussing YouTube and internet sources in general, faculty rarely expressed intellectual property concerns. It would also be useful to better understand how faculty use materials and whether they simply provide students with sources or list citations to encourage information literacy skills (our findings suggest the former). Finally, it would be beneficial to ascertain faculty's comfort levels with using the library and information literacy skills, especially in the performing arts where scholarship and research skills are frequently secondary to performance and applied skills.

In addition to further studies, libraries could investigate changes to better meet the needs of today's users. Some faculty indicated that they employed information-seeking behavior that is "low-effort," meaning that convenience was a primary driver in their process and that easier-to-use strategies are used over systematic, thorough inquiries. Libraries could develop approaches to meet these users' needs. Schwieder argues this point, offering an organized "toolkit" to assist in meeting low-effort information-seeking behavior approaches. ${ }^{26} \mathrm{He}$ suggests that low-effort approaches would "be an important component of the academic informationseeking paradigm" that might complement rather than compete with traditional strategies. ${ }^{27}$

Libraries could also investigate better integration of openly accessible score resources such as IMSLP and the Web Library of Seventeenth-Century Music into library search results, making them more discoverable and encouraging use of the library's online catalog. Integration of digitized collections held by national and research libraries such as the US Library of Congress, Bibliothèque nationale de France, and New York Public Library would also greatly enhance access. 
While some may fear the internet will one day replace the library, the vast majority of faculty respondents $(87 \%)$ relied on the library for instructional content. Services such as reserves and library instruction also continue to play a role in teaching. There seems to be a need for enhanced awareness of existing library resources, as well as improved communication between librarians and teaching faculty. These discussions might result in persuading faculty members to use library resources more often in their instruction. Conversely, this dialogue may result in librarians redirecting acquisition funds to other formats or resources. Armed with this kind of information, public service librarians may also be in a better position to advocate for more seamless resource access to their technical services department or vendors. As the information landscape rapidly evolves, libraries must continue to adapt to the changing terrain if they expect to thrive and not simply survive. 


\section{APPENDIX A. Qualtrics Survey}

When teaching courses, what materials do you typically require students to use (check all that apply)?

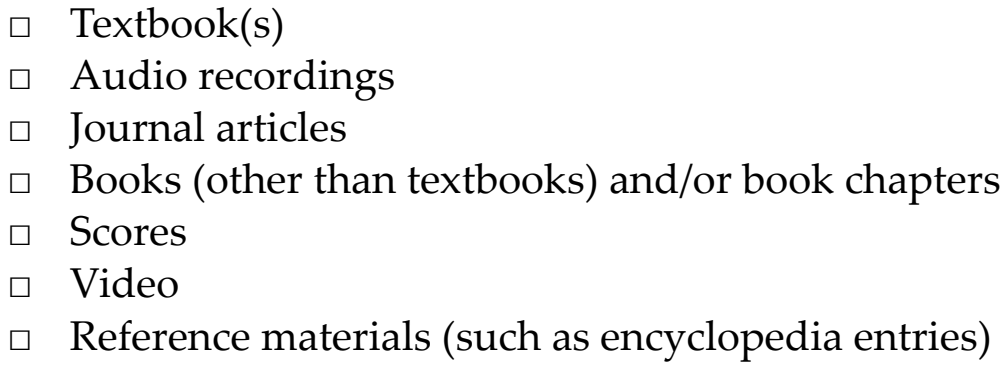

Do you require students to use library resources, or are they free to acquire the information however they can?

$\square$ Yes, I require use of specific library resources for some/all assignments.

$\square \quad$ No, I do not require use of library-owned materials for any assignments.

What library resources do you require students to use (check all that apply)?

$\square$ Journal articles

$\square$ Books/book chapters

$\square$ CDs

$\square \quad$ Streaming audio databases (such as Naxos)

$\square$ DVDs

$\square$ Streaming video databases (such as Kanopy)

$\square \quad$ Library print reference materials

$\square$ Online reference resources (such as Oxford Music Online)

$\square$ Scores

What types of formats do you use in your teaching/instruction that are NOT from the library (list all that apply)?

$\square \quad$ Personal media (CDs, DVDs)

$\square \quad$ Freely available media from the internet (such as YouTube or Spotify)

$\square$ Media files loaded into course management system (such as Blackboard, Moodle, eCollege, or Canvas)

$\square$ PDF/text files loaded into course management system (such as Blackboard, eCollege, or Canvas)

$\square \quad$ Other (please list)

What materials should the library prioritize for future purchase to support your instruction (check all that apply)?

$\square \quad$ Print books

E-books

$\square \quad$ Print scores

$\square$ Score databases with scores for download/printing

$\square$ CDs

$\square$ Streaming audio databases (such as Naxos or Classical Music Library)

$\square$ DVDs 
$\square \quad$ Streaming video databases (with performances, master classes, and the like)

$\square \quad$ Print journals

$\square \quad$ Electronic journals

$\square$ Print reference materials (such as encyclopedias, thematic catalogues, or dictionaries)

$\square$ Electronic reference material databases (such as Oxford Music Online or Grove Music Online)

\section{Display This Question:}

What materials should the library prioritize for future purchase to support your instruction? (If Selected Choices Count Is Greater Than or Equal to 2, Carry Forward Selected Choices from "What materials should the library prioritize for future purchase to support your instruction?")

Of the choices you selected, rank-order the materials you want the library to prioritize for purchase ( 1 = highest priority):

Print books

E-books

Print scores

Score databases with scores for download/printing

CDs

Streaming audio databases (such as Naxos or Classical Music Library)

DVDs

Streaming video databases (with performances, master classes, and the like)

Print journals

Electronic journals

Print reference materials (such as encyclopedias, thematic catalogues, or dictionaries) Electronic reference material databases (such as Oxford Music Online or Grove Music Online)

Indicate your level of satisfaction with the library's current offerings of the following formats:

\begin{tabular}{|l|l|l|l|l|l|l|}
\hline & $\begin{array}{c}\text { Very } \\
\text { Satisfied }\end{array}$ & Satisfied & Neutral & Dissatisfied & $\begin{array}{c}\text { Use but } \\
\text { Don't Know }\end{array}$ & $\begin{array}{c}\text { Do Not } \\
\text { Use }\end{array}$ \\
\hline Print books & & & & & & \\
\hline E-books & & & & & & \\
\hline Print scores & & & & & & \\
\hline CDs & & & & & & \\
\hline Streaming audio (such as Naxos) & & & & & & \\
\hline DVDs & & & & & & \\
\hline $\begin{array}{l}\text { Streaming video databases } \\
\text { (such as Kanopy) }\end{array}$ & & & & & & \\
\hline Print journals & & & & & & \\
\hline $\begin{array}{l}\text { Electronic journal databases } \\
\text { (such as JSTOR or EBSCO) }\end{array}$ & & & & & & \\
\hline Print reference books & & & & & & \\
\hline Electronic reference sources & & & & & & \\
\hline
\end{tabular}


Please indicate the source of your teaching materials in percentages (totaling 100\%):

Content from the library:

Content from my personal collection:

Content from the internet:

Other (please list):

Total:

I typically use the following library services to support my teaching (check all that apply):

$\square \quad$ Physical library reserves (such as print or media)

$\square \quad$ Electronic library reserves (print and media)

$\square \quad$ Playlists and direct link access to audio recordings through the library

$\square$ Direct link access to video recordings through the library

$\square \quad$ Class instruction by a librarian (1 class or more)

$\square \quad$ Short library introduction by library personnel (15 minutes or less)

$\square \quad$ I recommend specific titles for the library to purchase to support my class curriculum

$\square$ Other (please specify):

$\square$ None

What factors keep you from using (more) library resources in your classroom teaching/instruction (check all that apply)?

$\square \quad$ I don't know what the library offers or has available

$\square \quad$ Inconvenience (please specify)

$\square$ Students have too much trouble locating and using physical resources in the library

$\square$ Students have too much trouble using the library website

$\square \quad$ Library does not have the materials that I need

$\square$ Other (please specify)

Please include any additional thoughts on how the library can support your classroom teaching/instruction:

What is your faculty status?

$\square$ Adjunct

$\square$ Full-time nontenure track

$\square$ Full-time tenure track/tenured

$\square \quad$ Other (please specify)

What is your age?
$\square<30$
$31-40$
$41-50$
51-60
61-70
$71-80$
$\square \quad 81+$ 
How many years have you taught at the college/university level?
$\square<5$
$\quad 6-10$
11-15
16-20
21-25
26-30
$31+$

What is your area?

$\square$ Music education

$\square$ Music performance/conducting

Music history/musicology

Ethnomusicology

Music theory/composition

$\square$ Dance

$\square$ Theatre

$\square \quad$ Other (please specify)

\section{APPENDIX B. Faculty Interview Questions}

What types of materials do you require that students use in your teaching?

Do you use freely available internet resources in your teaching? If yes, why (familiarity, ease of access, or other reasons)?

Have you noticed that students encounter difficulties in finding library materials?

Do you prefer freely available internet resources in your teaching over library resources? Why/why not?

What does the academic library collection of the future look like in your discipline?

What can the library buy more of to better support your teaching?

Are there other things the library could do to better support your teaching? 


\section{Notes}

1. "2015-2016 Rutgers University Fact Book," available online at https://oirap.rutgers.edu/instchar/factbook. html [accessed 13 March 2018].

2. "Degree Programs I Mason Gross School of the Arts," available online at www.masongross.rutgers.edu/ departments [accessed 13 March 2018].

3. Carol Hansen Montgomery, "The Evolving Electronic Journal Collection at Drexel University," Science \& Technology Libraries 24, no. 1/2 (2004): 173-86; Gary Ives, "Transition to E-Journals at Texas A\&M University, 1995-2004," The Serials Librarian 47, no. 4 (2005): 71-78; Claire T. Dygert, "Going Online-Only with Journal Content: American University Library Takes the Plunge," Against the Grain 17, no. 6 (2005): 22-24; William H. Mischo et al., "The Growth of Electronic Journals in Libraries: Access and Management Issues and Solutions," Science E Technology Libraries 26, no. 3/4 (2007): 29-59.

4. Erin Dorris Cassidy, Michelle Martinez and Lisa Shen, "Not in Love, or Not in the Know? Graduate Student and Faculty Use (and Non-use) of E-Books," Journal of Academic Librarianship 38, no. 6 (2012): 326-32; Joe C. Clark, "Format Preferences of Performing Arts Students," Journal of Academic Librarianship 39, no. 3 (2013): 297-307.

5. Weijing Yuan, Marlene Van Ballegooie and Jennifer L. Robertson, "E-books Versus Print Books: Format Preferences in an Academic Library," Collection Management 43, no. 1 (2018): 40.

6. Bernd W. Becker, "E-books in the Library: The Current State of Research," Behavioral \& Social Sciences Librarian 34, no. 4 (2015): 231.

7. Amanda J. Rockinson- Szapkiw et al., Electronic Versus Traditional Print Textbooks: A Comparison Study on the Influence of University Students' Learning 63 (2013): 259-66.

8. Michael Levine-Clark, "Electronic Books and the Humanities: A Survey at the University of Denver," Collection Building 26, no. 1 (2007): 12.

9. Andy Revelle et al., “Book Lovers, Technophiles, Pragmatists, and Printers: The Social and Demographic Structure of User Attitudes toward E-Books," College E Research Libraries 73, no. 5 (2012): 420-29; Shannon Marie Robinson, "Artists as Scholars: The Research Behavior of Dance Faculty," College \& Research Libraries 77, no. 6 (2017): 785.

10. Sarah Buck Kachaluba, Jessica Evans Brady and Jessica Critten, "Developing Humanities Collections in the Digital Age: Exploring Humanities Faculty Engagement with Electronic and Print Resources," College $\mathcal{E}$ Research Libraries 75, no. 1 (2014): 92.

11. "IMSLP/Petrucci Music Library: Free Public Domain Sheet Music," available online at https:/imslp.org/ [accessed 27 February 2018]; "Music Online: Classical Scores Library," available online at and https://alexanderstreet.com/products/music-online-classical-scores-library [accessed 24 February 2018].

12. "C.P.E. Bach: The Complete Works," available online at https://cpebach.org/ [accessed 27 February 2018]; "Digital Mozart Edition Home," available online at https://dme-webdev.mozarteum.at/en/ [accessed 27 February 2018].

13. "Web Library of Seventeenth Century Music," available online at http://www.sscm-wlscm.org/ [accessed 27 February 2018].

14. Casey A. Mullin, "Review of International Music Score Library Project/Petrucci Music Library," Notes 67, no. 2 (2010): 376-81; Eunice Schroeder, "Review of Classical Scores Library," Notes 67, no. 2 (2010): 370-74; Clark, "Format Preferences of Performing Arts Students"; Keith Knop, "Music Library Patron Material Preferences: Use and Discovery of Resources in Print and Digital Formats," Music Reference Services Quarterly 18, no. 2 (2015): 79-99.

15. James Procell, "Trends in Patron Use of Physical Media Materials and Subscription Online Media Databases at the University of Louisville: A Ten-Year Study," Music Reference Services Quarterly 15, no. 4 (2012): 231-39.

16. Kirstin Dougan, "'YouTube has Changed Everything'? Music Faculty, Librarians, and their Use and Perceptions of YouTube," College \& Research Libraries 75, no. 4 (2014): 581.

17. Robinson, "Artists as Scholars: The Research Behavior of Dance Faculty," 785.

18. Robinson, "Artists as Scholars: The Research Behavior of Dance Faculty," 785.

19. Joe C. Clark and Amanda L. Evans, "Are Audio Reserves Still Relevant in Libraries?" Journal of Interlibrary Loan, Document Delivery \& Electronic Reserve 25, no. 1/2 (2015): 1-14.

20. Clark, "Format Preferences of Performing Arts Students."

21. A. Carey Huddlestun, "Just Tell Me What You Want: Collection Format Preference of Music Faculty," presented at the Southeast Chapter of the Music Library Association (October 2016), available online at http:// semla.musiclibraryassoc.org/semla2016/presentations/Huddlestun_SEMLA_2016_10_Material_Format_Pref.pdf [accessed 20 March 2018]. 
22. Kirstin Dougan, "Music, YouTube, and Academic Libraries," Notes 72, no. 3 (2016): 505-07.

23. Kirstin Dougan, “Music, YouTube, and Academic Libraries," Notes 72, no. 3 (2016): 505-07.

24. Anselm Strauss and Juliet Corbin, Basics of Qualitative Research: Grounded Theory Procedures and Techniques (Newbury Park, CA: Sage, 1990).

25. Butler University Libraries discontinued electronic reserves due to faculty inserting content directly into their course management system.

26. David Schwieder, "Low-Effort Information Searching: The Heuristic Information-Seeking Toolkit," Behavioral \& Social Sciences Librarian 35, no. 4 (2016): 171-87.

27. Schwieder, "Low-Effort Information Searching," 185.

28. Faculty who identified as working in "other" areas outside of traditional theatre, music, or dance were included in these totals but not categorized into their own column. 